\title{
Long-term efficacy of gliflozins versus gliptins for Type 2 Diabetes after metformin failure: a systematic review and network meta-analysis
}

\author{
Renato Wilberto Zilli \\ DChennyfer Dobbins Abi Rached ${ }^{2}$ \\ (iD) Fabiano Pinheiro da Silva ${ }^{3}$ \\ (iD) Renato Corrêa Baena ${ }^{4}$
}

1. Universidade de São Paulo, São Paulo, Brasil 2. Programa de Mestrado em Gestão de Sistemas de Saúde, Universidade Nove de Julho (Uninove), São Paulo, SP, Brasil 3. Departamento de Medicina de Emergência, Universidade de São Paulo, São Paulo, Brasil 4. Departamento de Clínica Médica, Universidade de São Paulo, São Paulo, Brasil

http://dx.doi.org/10.1590/1806-9282.66.4.458

\begin{abstract}
SUMMARY
After metformin failure in treatment for diabetes type 2, there is no trivial option for adjuvant medication. The last two oral class medications, gliflozins and gliptins, have different mechanisms of action but have never been compared in long run studies. The aim of the present meta-analysis is to assess the overall long-term efficacy of these drugs after metformin failure. A systematic review and meta-analysis were performed, including all trials with a duration of over 2 years, comparing gliflozins or gliptins after metformin failure in type 2 diabetes. Data Sources: Pubmed (Medline), Embase, Lilacs, and the Cochrane Library from inception through July 2016 without language restrictions. The longest study period found in the literature was 4 years. We selected 1 article on empagliflozin, 1 on dapagliflozin, and 1 on saxagliptin with missing data. After one year of treatment, over $50 \%$ of the patients presented $\mathrm{HbA} 1 \mathrm{C}>7 \%$. Efficacy rate after 4 years of empagliflozin (23\%) was better than dapagliflozin (5\%) and saxagliptin (7\%); however, it presented statistically non-significant values for HbA7c (7.4 and 7.3\% between gliflozins), and missing data for saxaglifozin. Nonetheless, empagliflozin performed better than glimepiride in the 4-year period (standardized mean difference SMD 0.4, confidence interval Cl $95 \% 0.23$ to 0.56). The failure of the secondary treatment using gliflozins occurs in less than one year of treatment (less than 50\% of the patients presenting $\mathrm{HbA1c}>7 \%$ ). Empagliflozin offered better glycemic control compared to sulfonylureas but was similar to dapagliflozin.
\end{abstract}

KEYWORDS: Diabetes mellitus, type 2. Metformin. Dipeptidy/-peptidase IV inhibitors.

\section{INTRODUCTION}

Type 2 diabetes mellitus (T2D) accounts for more than $90 \%$ of cases of diabetes. It is a typical progressive disease characterized by the gradual deterioration of pancreatic $\beta$-cell function and basal insulin resistance'. Although metformin is the primary drug of choice, it fails within nearly 2 years ${ }^{2}$. The choice of the second drug after metformin failure considers several factors, such as weight gain, risk of hypoglycemia, side effects, and cost; however, none of the consensuses considers the time of failure of the drug in the therapeutic choice ${ }^{3,4}$.

More recently, two new classes of glucose-lowering agents were put into the market. Gliptins (dipeptidyl peptidase-4 inhibitors) increase the incretin effect in vitro, prolonging the action of native GLP-1 ${ }^{5}$. Drugs from this class have similar efficacy in reducing HbA1c

DATE OF SUBMISSION: 21-JUn-2019

DATE OF ACCEPTANCE: 29-Jun-2019

CORRESPONDING AUTHOR: Chennyfer Rached

Rua Barata Ribeiro, 237 cj 64, Bela Vista - São Paulo, Brasil, zip code 01300-001

E-mail: chennyferr@yahoo.com.br 
levels, presenting satisfactory levels of safety and tolerance $^{6}$. The newest class, gliflozins (sodium-glucose co-transporter-2 inhibitors), act by increasing urinary glucose excretion regardless of insulin secretion ${ }^{7}$. Their main advantages are weight loss and low risk of hypoglycemia ${ }^{8}$.

Gliptins and gliflozins have been investigated after metformin failure in several randomized controlled trials (RCTs) and short-term meta-analysis. Their efficacy and safety were evaluated in systematic reviews and meta-analyses within a period of less than 2 years ${ }^{9,10}$. However, there are neither direct long-term comparisons between the two classes nor a meta-analysis to address their efficacy.

Network meta-analysis (NMA) compare the effectiveness of interventions indirectly, in the absence of head-to-head studies ${ }^{11}$. In addition, NMA has been acknowledged as a key health care decision-making tool that is increasingly recognized, given the possibility of classifying treatments according to efficacy and safety ${ }^{11}$.

The primary objective of this study is to estimate the efficacy of gliflozins versus gliptins after metformin failure. A long-term perspective (more than 2 years' follow-up) was selected to reflect diabetes management better.

\section{METHODS}

\section{Data Sources and Searches}

A systematic literature review was conducted to identify RCTs involving gliptins and gliflozins in T2D inadequately controlled using metformin monotherapy. Details of the search strategies are in Appendix S1. This study was conducted according to the methods and recommendations from the Cochrane handbook ${ }^{12}$.

Searches were conducted in July 2017 in electronic databases (EMBASE, MEDLINE via Pubmed, LILACS, and the Cochrane Central Register of Controlled Trials); 2016 conference proceedings [European Association of the Study of Diabetes (EASD), American Diabetes Association (ADA), American College of Cardiology (ACC)]; and clinical trial registry [clinicaltrials. gov]. An updated review of electronic databases was performed in March 2018. Language was not an exclusion criterion. The selection of the studies considering inclusion criteria and data extraction were performed by two independent reviewers, to reduce bias. The meta-analysis protocol was published on Prospero database CRD42015026155.

\section{Study Selection}

Initially, eligible studies were RCTs of 52 weeks' duration, conducted among adults with T2D inadequately controlled on metformin monotherapy. Studies shorter than 52 weeks were excluded, as the initial effect of treatment may not be maintained in the longer-term. To have meaningful results, we aimed to compare studies presenting the longest periods possible found in the literature. Placebo- and active-controlled RCTs comparing two or more drug classes of interest were included. When the study used several doses of the drug in a fixed manner, the usual dose of clinical use was included in the analysis. The treatment efficacy (percentage of patients with HbA1c < 7\%), HbA1c levels, weight variation, and frequency of hypoglycemia were analyzed.

\section{Data Extraction and Quality Assessment}

After the identification of eligible studies, the authors independently extracted data, using standardized predefined forms. For continuous variables (HbA1c and weight variation), we extracted outcome data such as the number of participants, mean difference, and standard error (or standard deviation). For dichotomous outcomes (frequency of patients with hypoglycemia and treatment efficacy), the total number of participants and events that were randomized and received treatment. Whenever studies reported different data for follow-up duration as an outcome, the longest one available was used. In cases where the independent reviewers disagreed on the eligibility of an article or data extraction, a consensus was reached by arbitration. The quality of the study was assessed using the Cochrane risk of bias tool ${ }^{12}$.

\section{Data Synthesis and Analysis}

We assumed a network meta-analysis within a Bayesian approach ${ }^{13}$, using $\mathrm{R}$ programming. We planned to measure heterogeneity and sensitivity analysis. Results were reported with $95 \%$ confidence intervals (CIs); we considered $p$ values $<0.05$ as statistically significant.

We used the results of the systematic review to create a network of evidence of the longest effect available (4 years of treatment). As a meta comparator, the sulfonylureas were chosen.

For HbA1c, we evaluated the therapeutic efficacy in years 1, 2, 3, and 4 (percentage of patients with HbA1c $<7 \%$ ) estimating a normal distribution in the absence of the data, performing a $Q^{2}$ test. When data was not 
available, we used DigitizeIt ${ }^{\circledR}$, a digitalization software, to capture the missing information.

A Summary of findings table was adapted to a network meta-analyses ${ }^{14}$.

\section{Outcomes}

From HbA1c and weight, variations from the baseline values were analyzed. Therapeutic efficacy was evaluated according to the percentage of patients presenting HbA1c $<7 \%$.

The proportion of subjects with at least one episode of hypoglycemia (regardless of the definition) was analyzed on an odds ratio scale.

\section{RESULTS}

From 2.496 identified records, we excluded non-human, less than 1 year duration RCTs and observational studies, leaving 164 reports for full-text assessment. After further selection (Figure 1), 3 unique RCTs fulfilled the inclusion criteria (Table 1) for the systematic review and had 4 years of duration. We selected 1 article on empagliflozin ${ }^{15}, 1$ on dapagliflozi ${ }^{16}$, and 1 on saxagliptin ${ }^{17}$ with missing data. The risk of bias table is available in Appendix S2.

Studies mentioned diet and activity recommendations but did not specify any guidance on how to execute them.

The definition of metformin failure (i.e. HbA1c inclusion criteria in the individual RCTs) varied across the included trials $6.5-10 \%$. In the study on dapagliflozin (DAPA), there was a progressive titration of the doses of dapagliflozin and glipizide up to 10 and $20 \mathrm{mg}$, respectively. In the study on empagliflozin (EMPA), there was a progressive titration of glimepiride up to $4 \mathrm{mg}$ and a fixed dose of empagliflozin $25 \mathrm{mg}$. In the study on saxagliptin (SAXA), we chose an arm with 5 $\mathrm{mg}$ and the placebo.

Mean baseline HbA1c ranged from 7,6 to 8,1\%. The mean change from baseline HbA1c observed in the individual trial arms ranged from -0.9 to $-0.2 \%$, (adjusted mean change) presented in Table 2.

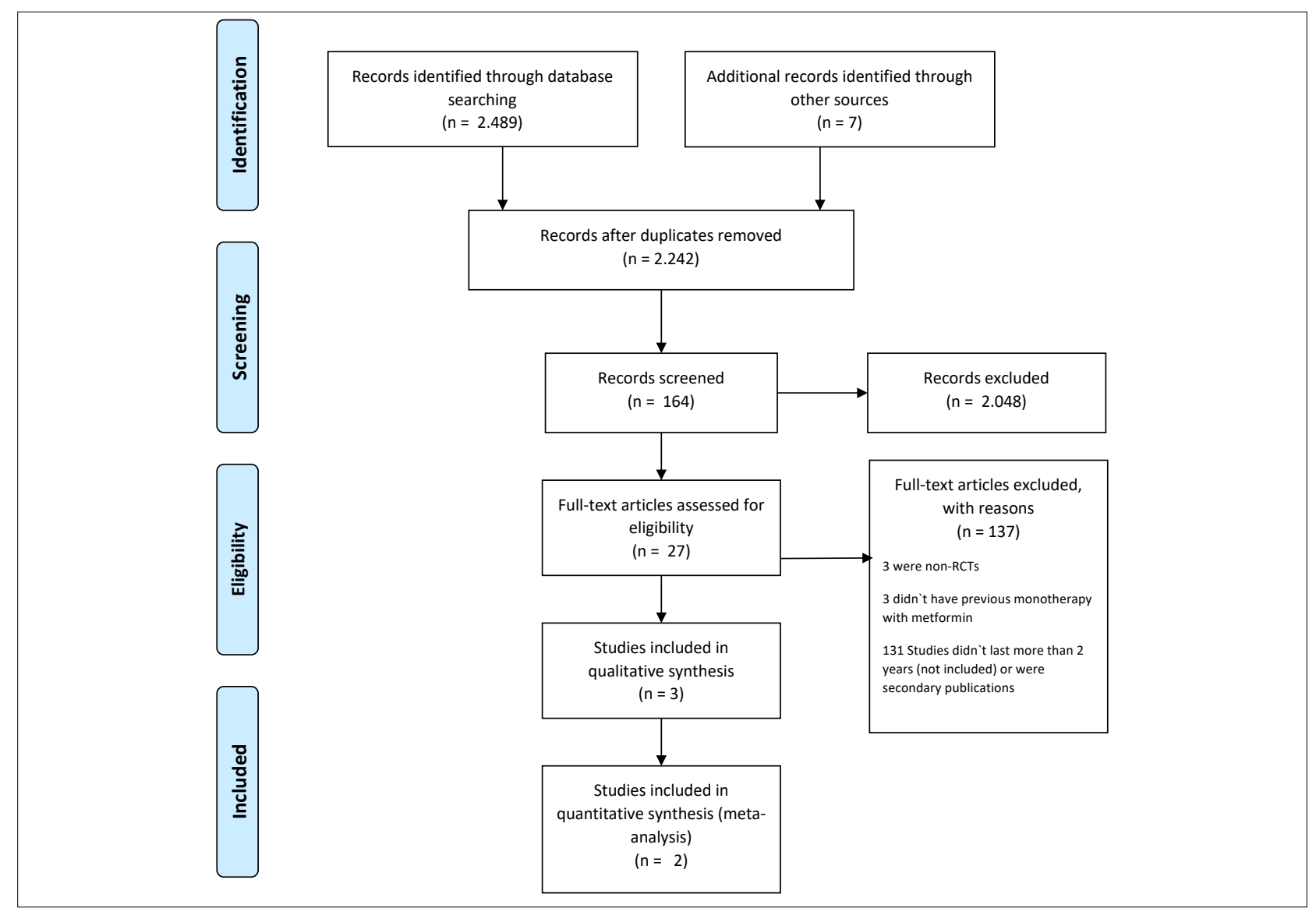




\section{TABLE 1. BASELINE CHARACTERISTICS OF THE SELECTED STUDIES}

\begin{tabular}{|c|c|c|}
\hline Study & Participants and baseline characteristics & Intervention / outcome \\
\hline $\begin{array}{l}\text { Del Prato et al., } 2015 \\
\text { Multicenter study }(\mathrm{n}=77) \\
\text { ClinicalTrials Registry: NCT00660907 } \\
\text { Design: } 2 \text { arms, double-blind, randomized, } \\
\text { dapagliflozin } 2.5-10 \mathrm{mg} \text {, comparator glipizide } \\
5-20 \mathrm{mg} \\
\text { Duration: } 2 \text { years with extension of } 2 \text { years }\end{array}$ & $\begin{array}{l}\text { N: } 814 \\
\text { Participants: patients with T2M on metformin } \\
\text { pre-randomization (> } 1500 \mathrm{mg} / \mathrm{d} \text { ) or associated } \\
\text { to another suspended medication and titration } \\
\text { of metformin } \\
\text { Age (years): dapagliflozin + met } 58 \pm 9 \text {; lipizide + } \\
\text { met } 59 \pm 10 \\
\text { Basal HbA1c (\%): dapagliflozin + met } 7.6+0.9 \text {; } \\
\text { glipizide + met } 7.7+0.9 \\
\text { Basal weight (Kg): No data available }\end{array}$ & $\begin{array}{l}\text { Intervention: dapagliflozin 2.5-10 mg } \\
\text { Comparator: glipizide 5-20 mg } \\
\text { Primary outcome: mean change in HbA1c } \\
\text { at } 52 \text { weeks } \\
\text { Secondary outcomes: weight change at } 52 \\
\text { weeks, proportion of patients with at least } \\
1 \text { episode of hypoglycemia, patients with } \\
\text { weight reduction greater than } 5 \%\end{array}$ \\
\hline $\begin{array}{l}\text { Salsali et al, } 2016 \\
\text { Multicenter study ( } \mathrm{n}=182 \text { ) } \\
\text { ClinicalTrials Registry: NCT01167881 } \\
\text { Design: } 2 \text { arms, double-blind, randomized, } \\
\text { empagliflozin 25mg, comparator glimepiride } \\
\text { 1-4 mg } \\
\text { Duration: } 2 \text { years with extension of } 2 \text { years }\end{array}$ & $\begin{array}{l}\text { N: } 1549 \\
\text { Participants: patients with T2M on metformin (> } \\
1500 \text { mg/d). } \\
\text { Age (years): empagliflozin + met } 56.2 \pm 10 \\
\text { glimepiride + meth } 55.7 \pm 10 \\
\text { Basal HbA1c (\%): empagliflozin+ met } 7.9 \pm 0.8 \text {; } \\
\text { glimepiride + met } 7.9 \pm 0.9 \\
\text { Basal weight (Kg): empagliflozin + met } 82.5 \pm 19 \\
\text { glimepiride + met } 83 \pm 19\end{array}$ & $\begin{array}{l}\text { Intervention: empagliflozin } 25 \text { mg } \\
\text { Comparator: glimepiride } 1-4 \text { mg } \\
\text { Primary outcome: mean change in HbA1c } \\
\text { at } 104 \text { weeks } \\
\text { Secondary outcomes: weight change at } \\
104 \text { weeks, variation of systolic and diastol- } \\
\text { ic blood pressure at } 104 \text { weeks }\end{array}$ \\
\hline $\begin{array}{l}\text { Rosenstock et al., } 2013 \\
\text { Multicenter study }(\mathrm{n}=154) \\
\text { ClinicalTrials Registry: NCT00121667 } \\
\text { Design: } 4 \text { arms, double-blind, randomized, } \\
\text { saxagliptin 2.5, 5, and } 10 \text { mg, placebo as a } \\
\text { comparator. Rescue drug pioglitazone 15-45 } \\
\text { mg. Only included the } 5 \text { mg dose in the } \\
\text { analysis. } \\
\text { Duration: } 4 \text { years }\end{array}$ & $\begin{array}{l}\text { N: } 743 \\
\text { Participants: patients with T2M on metformin (> } \\
1500 \text { mg/d). } \\
\text { Age (years): saxagliptin + met } 54.7 \pm 9 \text {; Placebo + } \\
\text { met } 54.8 \pm 10 \\
\text { Basal HbA1c }(\%) \text { : saxagliptin + met } 8.1 \pm 0.1 ; \\
\text { Placebo + met } 8.1 \pm 0.1 \\
\text { Basal weight (Kg): No data available }\end{array}$ & $\begin{array}{l}\text { Intervention: saxagliptin } 5 \text { mg } \\
\text { Comparator: placebo } \\
\text { Primary outcome: mean change in HbA1c } \\
\text { at } 25 \text { weeks } \\
\text { Secondary outcomes: fasting blood glu- } \\
\text { cose variation at } 24 \text { weeks, percentage of } \\
\text { patients reaching HbA1c }<7 \% \text { at } 24 \text { weeks }\end{array}$ \\
\hline
\end{tabular}

Met: metformin. Data presented in mean and standard deviation

TABLE 2. SUMMARY OF FINDINGS

What is the best therapeutic option after primary failure with metformin in the long term?

Patients: T2D with primary metformin failure

Interventions: dapagliflozin and empagliflozin

Comparator: Sulfonylureas (glipizide and glimepiride)

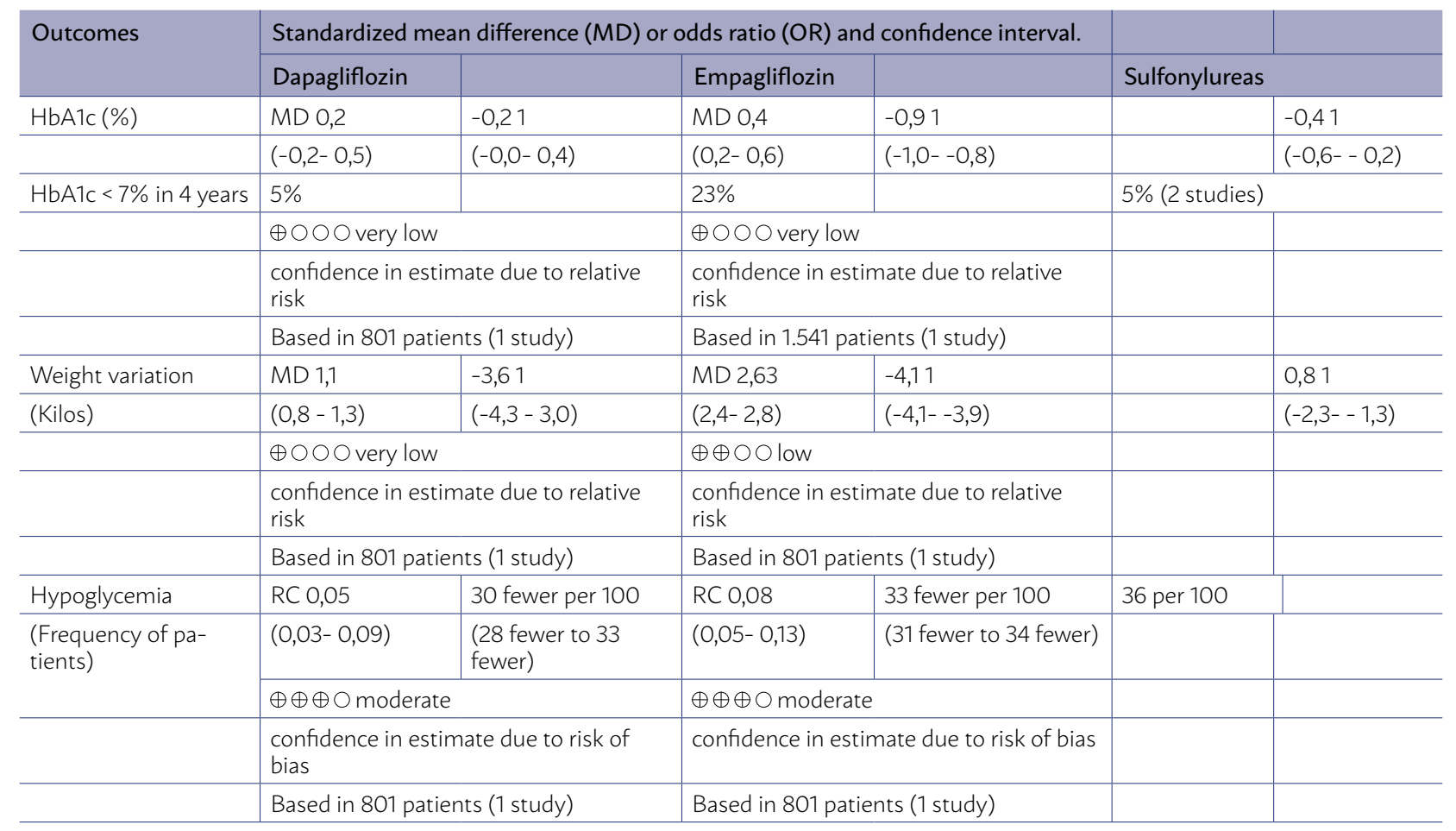

1. Compared with the baseline value 
Efficacy rate $(\mathrm{HbA1c}<7 \%)$ in 1 year of treatment was 35 and $43 \%$, for dapagliflozin and empagliflozin, respectively. In 4 years of treatment, empagliflozin (23\%) was statistically significantly better than dapagliflozin (5\%) and saxagliptin (7\%), data presented in Appendix S3.

Only the EMPA study presented results for baseline weight. Weight variation was negative for gliflozins and positive for sulfonylureas (Table 2).

For the meta-analysis, only the DAPA and EMPA studies had a meta comparator (sulfonylurea) and were eligible. In the arms comparison of the DAPA study (dapagliflozin versus glipizide), the HbA1c variation did not present statistical significance at the end of the study. In the EMPA study (empagliflozin versus glimepiride), there was a significant reduction in the HbA1c (SMD: 0.40, CI 95\% 0.23 to 0.56). In the meta-comparison between dapagliflozin and empagliflozin, there was no statistical significance, presented in Figure 2.

Comparing bodyweight variation, in the DAPA study, the weight variation was statistically significant, favoring dapagliflozin (SMD: 1.07, CI 95\% 0.83 to 1,32). In the EMPA study, the analysis also showed statistical significance favoring empagliflozin (SMD: 2.63, CI 95\% 2.4 to 2.85). In the meta-comparison between dapagliflozin and empagliflozin, there was statistical significance favoring empagliflozin (SMD: 1.56, CI 95\% 1.22 to1.88), presented in Figure 2.
The frequency of patients with hypoglycemia was significantly higher in the sulfonylureas arms in DAPA study (OR:0.05, CI 95\% 0.03 to 0.09) and in the EMPA study (OR: 0.08, CI 95\% 0.05 to 0.13). In the meta-comparison between dapagliflozin and empagliflozin, there was no statistical significance (Figure 2).

Due to the low availability of studies, it was not possible to measure heterogeneity and run a sensitivity analysis.

\section{DISCUSSION}

The medical literature lacks RCTs to evaluate the efficacy of gliflozins and gliptins for T2D after monotherapy failure using metformin in the long-term. This has been the first review to address this question.

The efficacy of dapagliflozin and empagliflozin were less than $50 \%$ in one year, suggesting that glycemic control becomes insufficient within the first years of the study for most of the patients. Results recently published from the Canvas Trial Program, designed to evaluate cardiovascular outcomes, compared canagliflozin and placebo associated to basal therapy (metformin $>77 \%$ of the patients) and showed they were unable to sustain glycemic control for more than 6 years, evidencing a progressive deterioration over time $^{18}$. Abdul-Ghani et al. ${ }^{19}$, in 2015, suggest a three-medicament treatment in patients with diabetes recently diagnosed was more efficient to reduce HbA1c

FIGURE 2. A: COMPARISON OF HBATC (\%) VARIATION FROM BASELINE. B: COMPARISON OF WEIGHT VARIATION (KG) FROM BASELINE. C: COMPARISON OF THE FREQUENCY OF PATIENTS WITH HYPOGLYCEMIA. SD= STANDARD DEVIATION, MD: STANDARDIZED MEAN DIFFERENCE, OR: ODDS RATIO, CI95\%L = LOWER LIMIT 95\% CONFIDENCE INTERVAL, CI95\%U = UPPER LIMIT 95\% CONFIDENCE INTERVAL.

\begin{tabular}{|c|c|c|c|c|c|c|c|c|c|c|c|c|c|c|}
\hline \multirow[b]{2}{*}{ A } & \multirow[b]{2}{*}{ Treatment 1} & \multirow[b]{2}{*}{ Treatment 2} & \multicolumn{3}{|c|}{ Treatmentt 1} & \multicolumn{3}{|c|}{ Treatmentt 2} & \multicolumn{3}{|c|}{ Treatment effect } & & \multirow[b]{2}{*}{.} \\
\hline & & & Mean & SD & Total & Mean & SD & Total & MD & Cl95\%L & $\mathrm{Cl} 95 \% \mathrm{U}$ & & & \\
\hline Del Prato et al. ${ }^{16}$ & DAPAGLIFLOZIN & SU & 7.550 & 0.680 & 79 & 7.550 & 0.645 & 71 & 0.151 & $-0,170$ & 0.471633914 & & & $\bullet$ \\
\hline \multirow[t]{3}{*}{ Ridderstrale et al. ${ }^{15}$} & EMPAGLIFLOZIN & SU & 7.270 & 0.390 & 365 & 7.440 & 0.477 & 243 & 0.398 & 0.234 & 0.562024521 & & & $\bullet$ \\
\hline & DAPAGLIFLOZIN & EMPAGLIFLOZIN & 7.550 & 0.680 & 79 & 7.270 & 0.390 & 265 & 0.248 & $-0,113$ & 607904928 & $\sqrt{10}$ & 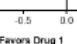 & is 10 \\
\hline & & & \multicolumn{3}{|c|}{ Treatmentt 1} & \multicolumn{3}{|c|}{ Treatmentt 2} & \multicolumn{3}{|c|}{ Treatment effect } & & & - \\
\hline B & Treatment 1 & Treatment 2 & Mean & SD & Total & Mean & SD & Total & MD & Cl95\%L & $\mathrm{Cl} 95 \% \mathrm{U}$ & & & $\bullet$ \\
\hline Del Prato et al. ${ }^{16}$ & DAPAGLIFLOZIN & SU & -3.650 & 4.117 & 159 & 0.730 & 4.045 & 140 & 1.073 & 0.830 & 1.315 .482 .303 & & & $\bullet-1$ \\
\hline \multirow[t]{3}{*}{ Ridderstrale et al. ${ }^{15}$} & EMPAGLIFLOZIN & SU & -4.060 & 1.870 & 336 & 0.821 & 1.840 & 248 & 2.628 & 2.405 & 2.850 .421 .751 & 5 & 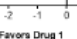 & $i i^{3}$ \\
\hline & DAPAGLIFLOZIN & EMPAGLIFLOZIN & -3.650 & 4.117 & 159 & $-4,060$ & 1.870 & 336 & 1.555 & 1.225 & 188.461 .348 & & & \\
\hline & & & \multicolumn{3}{|c|}{ Treatmentt 1} & \multicolumn{3}{|c|}{ Treatmentt 2} & \multicolumn{3}{|c|}{ Treatment effect } & & • & \\
\hline C & Treatment 1 & Treatment 2 & Prop & $\begin{array}{l}\text { Number } \\
\text { of Cases }\end{array}$ & Total & Prop & $\begin{array}{l}\text { Number } \\
\text { of Cases }\end{array}$ & Total & OR & $\mathrm{Cl} 95 \% \mathrm{~L}$ & $\mathrm{Cl} 95 \% \mathrm{U}$ & & • & \\
\hline Del Prato et al. ${ }^{16}$ & DAPAGLIFLOZIN & SU & 0.05 & 22 & 406 & 0.51 & 210 & 408 & 0.05 & 0.03 & 0.09 & -1 & $\dot{i}$ & $\underset{2}{2}$ \\
\hline \multirow[t]{2}{*}{ Ridderstrale et al. ${ }^{15}$} & EMPAGLIFLOZIN & su & 0.03 & 24 & 765 & 0.28 & 218 & 780 & 0.08 & 0.05 & 0.13 & & & Favors \\
\hline & DAPAGLIFLOZIN & EMPAGLIFLOZIN & 0.05 & 22 & 406 & 0.03 & 24 & 765 & 1.53 & 0.80 & 2.91 & & & \\
\hline
\end{tabular}


and presented less hypoglycemia when compared to the progressive adoption of a three-medicament treatment along two years. It is possible that the time wasted up to the moment of failure in the primary treatment can be related to a significant loss of $\beta$ cell functionality in the selected studies of this analysis, similar to the one found in the literature. The consensus provided by the American Diabetes Association and American Association of Clinical Endocrinology ought to consider the time of failure of the drugs, aside from weight, cost, side effect, and drug efficacy when recommending a second drug therapy.

In the selected studies, dapagliflozin and empagliflozin were compared to sulfonylureas (glipizide and glimepiride respectively) titration, allowing it to be up to half of the maximum dose. Medical literature shows scarce comparisons between sulfonylureas ${ }^{20}$. In the DAPA study, only $63 \%$ of the patients in the glipizide arm received the maximum titration dose of 20 $\mathrm{mg}^{16}$. There are no 4-year data referring to the mean dose of glimepiride in the EMPA study; however, in the 2 -year publication, only $40 \%$ of the patients in the glimepiride group used the allowed maximum dose in the $4 \mathrm{mg}^{21}$. In a study comparing canagliflozin versus glimepiride after the failure of metformin as primary treatment, which was not included in this review, for it lasts 2 years, the titration of glimepiride was done up to the maximum recommended dose of $8 \mathrm{mg} / \mathrm{d}^{22}$. Although some publications in the medical literature point that the efficacy between half a dose and the full dose of sulfonylureas would have similar effects ${ }^{20}$. We can conclude that one cannot characterize therapeutic equivalence or superiority of gliflozins in the selected studies in patients who did not reach the recommended half dose of the sulfonylureas. Additionally, hypoglycemia could have been a limiting factor in the titration of the sulfonylureas.

The meta-comparison of HbA1c between both gliflozins showed no significant difference. To interpret this result, it is important to consider that the criteria for rescue and titration from each study were different. This analysis presents a low level of quality of evidence due to severe inconsistency (heterogeneity which could not be calculated) and severe inaccuracy (only 2 studies).

Both gliflozins demonstrated weight loss when compared to sulfonylureas, and in the meta-comparison, empagliflozin performed better than dapagliflozin. The variation of weight loss was maintained for 4 years for gliflozins compared to sulfonylureas
(Appendix S4). Those data must be analyzed considering potential confounders, such as the progressive titration of dapagliflozin, the employed methodology for incomplete data in each study (LOCF versus MMRM), and the fact that in the DAPA study the results of weight variation included patients after the therapeutic rescue.

Hypoglycemia is a main concern in diabetes treatment, especially in patients using sulfonylureas. In this review, we demonstrated a low frequency of patients with hypoglycemia under the class of gliflozins in a 4-year period (dapagliflozin 5\% and empagliflozin 3\%) compared to sulfonylureas (glipizide 52\% and glimepiride 28\%). This result must be evaluated since each study has had its own objective and subjective criteria of hypoglycemia.

Other factors not evaluated in this systematic review that can impact the clinical use of gliflozins and gliptins are the adverse effects and cardiovascular safety. The medical literature has been showing a higher risk of urinary infection ${ }^{23}$ and a beneficial cardiovascular profile of gliflozins ${ }^{18,24}$.

\section{LIMITATIONS}

A critical assumption underlying NMA is related to exchangeability, i.e., that trials selected are sufficiently similar in design, outcomes, and population. Potential limitations of this NMA network were the number of studies, the study designs, and losses during the follow-up. Other crucial factors to be considered are incomplete data of the outcomes (especially missing data of LOCF vs. MMRM strategies), selective narratives, and performance (sub dose of sulfonylureas as a comparator).

\section{CONCLUSION}

More long-term studies are required to evaluate the efficacy of gliptins and gliflozins after the therapeutic failure of metformin monotherapy in patients with T2D.

The efficacy of the treatment, defined by the percentage of patients with $\mathrm{HbA1c}<7 \%$, is low in the first years of treatment with gliflozins. In 4 years of treatment, the efficacy profile of empagliflozin (23\%) performed better than saxagliptin (7\%) and dapagliflozin (5\%); however, with average values of HbA1c that were statistically non-significant.

The variation of weight loss was maintained in 4 
years for gliflozins compared to sulfonylureas, being more favorable to empagliflozin.

The frequency of patients with hypoglycemia was significantly better for gliflozins compared to sulfonylureas. There was no difference in the class of gliflozins.

The results of this systematic review and meta-analysis suggest careful analysis for generalizations to other populations. Further studies are required to evaluate the efficacy of glycemic control, weight variation, and frequency of hypoglycemia in the long-term after the introduction of gliflozins and gliptins after the primary failure of metformin in patients with T2D.

\section{Acknowledgments}

We thank Rosa Maria Fischi for technical assistance.

\section{Supporting information}

Appendix S1 - Search strategy; Appendix S2 - Risk of bias; Appendix S3 - Proportion of patients with HbA1c < 7\%; Appendix S4 - Variation of weight during 4 years of follow-up

\section{RESUMO}

Após a falha da metformina no tratamento do diabetes tipo 2, não existe uma opção trivial para a medicação adicional. Os dois últimos medicamentos de classe oral, gliflozinas e gliptinas, têm mecanismos de ação diferentes, mas nunca foram comparados em estudos de longo prazo. O objetivo da presente meta-análise é a avaliação da eficácia global em longo prazo desses medicamentos após a falha da metformina. Uma revisão sistemática e meta-análise foram realizadas, incluindo todos os ensaios com uma duração de mais de dois anos, comparando gliflozinas ou gliptinas após a insuficiência de metformina no diabetes tipo 2. Fontes de dados: PubMed (Medline), Embase, Lilacs e a Biblioteca Cochrane desde o início até julho de 2016, sem restrições de idioma. O período mais longo de estudo encontrado na literatura foi de quatro anos. Foi selecionado um artigo sobre empagliflozina, um artigo sobre dapagliflozina e um artigo sobre saxagliptina com dados faltantes. Após um ano de tratamento, mais de 50\% dos pacientes apresentavam $\mathrm{HbA1c}>7 \%$. A taxa de eficácia em quatro anos de empagliflozina (23\%) foi melhor que dapagliflozina (5\%) e saxagliptina (7\%), porém com valores estatisticamente não significativos para $\mathrm{HbA1c}$ (7,4\% e 7,3\% entre gliflozinas) e dados ausentes para a saxaglifozina. No entanto, a empagliflozina teve um desempenho melhor do que a glimepirida no período de quatro anos (diferença média padronizada SMD 0,4, intervalo de confiança IC 95\% 0,23 a 0,56). A falha do tratamento secundário com gliflozinas ocorre em menos de um ano de tratamento (menos de 50\% dos pacientes com HbA1c >7\%). A empagliflozina ofereceu melhor controle glicêmico em comparação com as sulfonilureias, mas semelhante à dapagliflozina.

PALAVRAS-CHAVE: Diabetes mellitus tipo 2. Metformina. Inibidores da dipeptidil peptidase IV.

\section{REFERENCES}

1. Defronzo RA. Banting Lecture. From the triumvirate to the ominous octet: a new paradigm for the treatment of type 2 diabetes mellitus. Diabetes. 2009;58(4):773-95

2. Brown JB, Conner C, Nichols GA. Secondary failure of metformin monotherapy in clinical practice. Diabetes Care. 2010;33(3):501-6.

3. American Diabetes Association. 8. Pharmacologic approaches to glycemic treatment. Diabetes Care. 2017;40(Suppl 1):S64-S74.

4. Garber AJ, Abrahamson MJ, Barzilay JI, Blonde L, Bloomgarden ZT, Bush MA, et al. Consensus Statement by the American Association of Clinical Endocrinologists and American College of Endocrinology on the comprehensive type 2 diabetes management algorithm - 2017 Executive Summary. Endocr Pract. 2017;23(2):207-38.

5. Baggio LL, Drucker DI. Biology of incretins: GLP-1 and GIP. Gastroenterology. 2007;132(6):2131-57.

6. Deacon CF. Dipeptidyl peptidase-4 inhibitors in the treatment of type 2 diabetes: a comparative review. Diabetes Obes Metab. 2011;13(1):7-18.

7. Kalra S. Sodium Glucose Co-Transporter-2 (SGLT2) inhibitors: a review of their basic and clinical pharmacology. Diabetes Ther. 2014;5(2):355-66.

8. Ferrannini E, Solini A. SGLT2 inhibition in diabetes mellitus: rationale and clinical prospects. Nat Rev Endocrinol. 2012;8(8):495-502.
9. Zaccardi F, Webb DR, Htike ZZ, Youssef D, Khunti K, Davies MJ. Efficacy and safety of sodium-glucose co-transporter-2 inhibitors in type 2 diabetes mellitus: systematic review and network meta-analysis. Diabetes Obes Metab. 2016;18(8):783-94.

10. Deacon CF, Mannucci E, Ahrén B. Glycaemic efficacy of glucagon-like peptide-1 receptor agonists and dipeptidyl peptidase-4 inhibitors as add-on therapy to metformin in subjects with type 2 diabetes: a review and meta analysis. Diabetes Obes Metab. 2012;14(8):762-7.

11. Jansen JP, Fleurence R, Devine B, Itzler R, Barrett A, Hawkins N, et al. Interpreting indirect treatment comparisons and network meta-analysis for health-care decision making: report of the ISPOR Task Force on Indirect Treatment Comparisons Good Research Practices: part 1. Value Health. 2011;14(4):417-28.

12. Higgins IP, Green S. Cochrane handbook for systematic reviews of interventions. Chichester: John Wiley \& Sons; 2008.

13. Hoaglin DC, Hawkins N, Jansen IP, Scott DA, Itzler R, Cappelleri JC, et al. Conducting indirect-treatment-comparison and network-meta-analysis studies: report of the ISPOR Task Force on indirect treatment comparisons good research practices: part 2. Value Health. 2011;14(4):429-37.

14. Puhan MA, Schunemann HI, Murad MH, Li T, Brignardello-Petersen $R$, Singh JA, et al. A GRADE Working Group approach for rating the 
quality of treatment effect estimates from network meta-analysis. BMJ. 2014;349:g5630

15. Ridderstrale M., Andersen KR, Toorawa R, Woerle HJ, Salsali A. Empagliflozin (EMPA) compared with glimepiride (GLIM) as add-on to metformin (MET) for 4 years in patients with type 2 diabetes (T2DM). 76th Scientific Sessions of the American Diabetes Association; 2016 June 10-14; New Orleans, Louisiana, USA. Disponível em: http://www.dagensdiabetes.info/ index.php/alla-senaste-nyheter/2247-ada-m-ridderstrale-et-al-empagliflozin-compared-with-glimepiride-as-add-on-to-metformin-for-4-yearsin-patients-with-t2dm-greater-red-hba1c-and-hypoglycemia Acessado em: 12.12.2019

16. Del Prato S, Nauck M, Durán-Garcia S, Maffei L, Rohwedder K, Theuerkauf A, et al. Long-term glycaemic response and tolerability of dapagliflozin versus a sulphonylurea as add-on therapy to metformin in patients with type 2 diabetes: 4-year data. Diabetes Obes Metab. 2015;17(6):581-90.

17. Rosenstock J, Gross JL, Aguilar-Salinas C, Hissa M, Berglind N, Ravichandran $\mathrm{S}$, et al. Long-term 4-year safety of saxagliptin in drug-naive and metformin-treated patients with type 2 diabetes. Diabet Med. 2013;30(12):1472-6.

18. Neal B, Perkovic V, Mahaffey KW, Zeeuw D, Fulcher G, Erondu N, et al; CANVAS Program Collaborative Group. Canagliflozin and cardiovascular and renal events in type 2 diabetes. N Engl J Med. 2017;377(7):644-57.

19. Abdul-Ghani MA, Puckett C, Triplitt C, Maggs D, Adams I, Cersosimo E, et al. Initial combination therapy with metformin, pioglitazone and exenatide is more effective than sequential add-on therapy in subjects with new-onset diabetes. Results from the Efficacy and Durability of Initial Combination Therapy for Type 2 Diabetes (EDICT): a randomized trial. Diabetes Obes Metab. 2015;17(3):268-75.

20. Oderda G, Richards K, Turpin S. Sulfonylurea agents \& combination products drug class review. Salt Lake City: University of Utah College of Pharmacy; 2013.

21. Ridderstrale M, Andersen KR, Zeller C, Kim G, Woerle HJ, Broedl UC, et al. Comparison of empagliflozin and glimepiride as add-on to metformin in patients with type 2 diabetes: a 104-week randomised, active-controlled, double-blind, phase 3 trial. Lancet Diabetes Endocrinol. 2014;2(9):691-700

22. Leiter LA, Yoon KH, Arias P, Langslet $G$, Xie J, Balis DA, et al. Canagliflozin provides durable glycemic improvements and body weight reduction over 104 weeks versus glimepiride in patients with type 2 diabetes on metformin: a randomized, double-blind, phase 3 study. Diabetes Care. 2015;38(3):355-64.

23. Shyangdan DS, Uthman OA, Waugh N. SGLT-2 receptor inhibitors for treating patients with type 2 diabetes mellitus: a systematic review and network meta-analysis. BMJ Open. 2016;6(2):e009417.

24. Fitchett D, Zinman B, Wanner C, Lachin JM, Hantel S, Salsali A, et al. Heart failure outcomes with empagliflozin in patients with type 2 diabetes at high cardiovascular risk: results of the EMPA-REG OUTCOME® trial. Eur Heart |. 2016;37(19):1526-34. 